報 文

[環境化学 (Joumal of Environmental Chemistry) Vol. 3, No. 4, pp. 739-746, 1993]

\title{
衝撃波の変異原性と変異原性修飾作用
}

\author{
玉川 勝美，庵谷 尚正 ${ }^{*}$ \\ 仙台市衛生研究所 \\ （９83 仙台市若林区卸町東 2 丁目 5-10) \\ *東北大学殍学部 \\ （テ980 仙台市青葉区星棱町 $2-1$ )
}

[平成 5 年 7 月 16 日受理 $]$

\section{Mutagenicity and mutagenic modifying effects of shock waves}

\author{
Katsumi TAMAKAWA and Naomasa IORITANI* \\ Sendai Municipal Institute of Public Health \\ (2-5-10 Oroshimachihigashi, Wakabayashiku, Sendai 98:3) \\ * Tohoku University, School of Medicine \\ (2-1 Seiryohcho, Aoba-ku, Sendai 980)
}

[Received July, 16, 1993]

\begin{abstract}
Summary
The Extracorponeal Shock Wave Lithotripy (ESWL) is well recognized to be one of the important clinical treatments for destruction of calculi in kidney and bladder by employing underwater shockwave focusing.However,the genotoxic effects of shock waves have not been clarified, yet. In this study,mutagenic and mutagenic modifying effects of shock waves were examined by using the Ames test.

Each bacterial tester strain (S. typhimurium TA98, TA100, TA97, TA102) and the mixture of tester strain and mutagen [cis-diaminedichloroplatinum (CDDP)] were shot by shock waves. Mutagenic response of shock waves was not detected in any strains, with and without S9 mix, by the shot of shock waves with maximal pressure between 0 and $100 \mathrm{MPa}$.

Mutagenic and cytotoxic effects of CDDP were enhanced after shock wave shots on the mixture of tester strain and CDDP, indicating that shock waves may have indirect effects on the genotoxicity of chemicals.
\end{abstract}

Key Words: ESWL, shock waves, mutagenicity, the Ames test, S.typhimurium strains, CDDP, enhancing effect

\section{1.はじめに}

最近，水中衝撃波が腎結石などの体内結石の破壊を目 的とする治療手段に利用されつつある。衝撃波や磁場, 超音波などの物理作用を診断や診療に心応用する試みは, 広く行われてきているがその生体影響，特に遺伝的影響 について論じた報告は比較的少ない。

衝撃波の生体影響について, 庵谷ら"は電顕による所
兒から腎の小動脈の中膜筋層や永細管上皮に細胞レベル の壞死や細胞内小器官の破壊が見られることを既に報告 している。また，衝撃波の細胞レベルでの障害について は大島ら゙2゙によっていくつかの報告がなされている。大 島らはフェニルアラニン脱水素酵素活性を增強した大腸 菌組換え体（E. Coli JM109/pKPDH2）のスフェロプラ ストを用い, 衝撃波照射の際に副次的に起きる細胞破壊 の程度を漏出醭素の活性を計ることによって調べてい 
る。その中で, 衝撃波による細胞破壊の際には発生する cavitation（気泡）が重要な役割を演じていることを示 した。また, 細胞内小器官を持つ真核細胞として酵䑠 (Candidaboidinii DSM 70026) を用いて，衝撃波の生物 影響を調へ，衝撃波の照射回数の増加とともに，生菌数 の減少が認められると述べている。

このような，細胞レベルでの障寒が，紫外線や放射線 などのようにDNA レベルでの障淎に起因している可能 性を必ずしも否定することはできない。

衝撃波の遺伝的影䈏についての報告は非常に少ない が, 大島ら 3'はS. typhimurium TA1535/pSK1002を用い た umuテストにより，衝撃波には変異原性は認められ ないことを報茫している。

本研究では変異原性試験法として一般に広く用いられ ているAmes テストにより、衝撃波の変異原性の有無に ついて検討を試みた。さらに，化学変異原の活性発現に 対する衝撃波照射の影響について考察を加えた。

\section{2. 方 法}

\section{1) 試薬}

1.2-benzopyrene (以下, B ( a)P と略す, 特級, 和光純薬), 2-(2-furyl) -3-(5-nitro-2-furyl) acrylamide（以下, AF-2 と略す, 特級, 和光純薬), 2-aminoanthracene (以 下，2-AA と略す，特級，和光純薬)，6-chloro-9- [3(2-ethyl-amino 9 propylamino]-2-methoxy-acridine (以 下, ICR-191と略す, SIGMA 社), mitomycin C (以下, MMC と略す, 生化学用, 和光純薬), cis. diaminedichloroplatinum（以下，シスプラチン，あるい はCDDP と略す，抗悪性腫瘍剂ランダ注ーシスプラチン 製剂，日本化薬)
S9（フェノバルビタール，ベンゾフラボンにより酵素 誘導, オリエンタル酵母)、コ・ファクター(混命凍結 乾燥品, オリエンタル酵母)

\section{2）街整波の照射方法}

片面にラテックス膜を張ったプラスチック製円简管を 消毒用アルコールで洗浄し，無菌箱内でよく乾燥した。 これにAmesテスト用の試験菌の前培養菌液 $3 \mathrm{ml}$ を人 れ，Fig. 1 に示すように， $37^{\circ} \mathrm{C}$ 温浴中で衝撃波発生装置 の焦点部セットし，衝撃波を照射した。衝撃波の発生に は以下の2つの方法を用いた。

[方法 1 (低压用)]

直径 $125 \mathrm{~mm}$, 曲率半径 $180 \mathrm{~mm}$ のワンピース型ピエゾ 素子を水中底部に固定し, 高圧駆動回路から高電厌パル

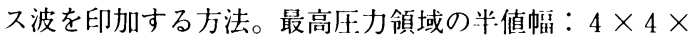
$37 \mathrm{~mm}$, ピーク压: $20 \mathrm{MPa}$

[方法 2 (高压用)]

值径 $300 \mathrm{~mm}$, 曲率半径 $260 \mathrm{~mm}$ のピエゾ素子 24 枚で構 成される装置を用い, 高厈駆動回路から高電厈パルス波 を印加する方法。最高压力領域の半值幅： $1 \times 1 \times$ $19 \mathrm{~mm}$, ピーク压：0〜100MPa で叮変

\section{3）変異原性試験}

変異原性試験は, Ames テスト (プレート法 $)^{4}$ を用い た。試験菌としてS. typhimurium TA97, TA98（フレー ムシフト型変異原検出用菌), TA100 (塩基対置換型検 出用菌）および, TA102 (架橋型変異原, 酸化型変異原 検出用菌）の 4 種を用い， $\pm \mathrm{S} 9$ mix の系で試験を行った。

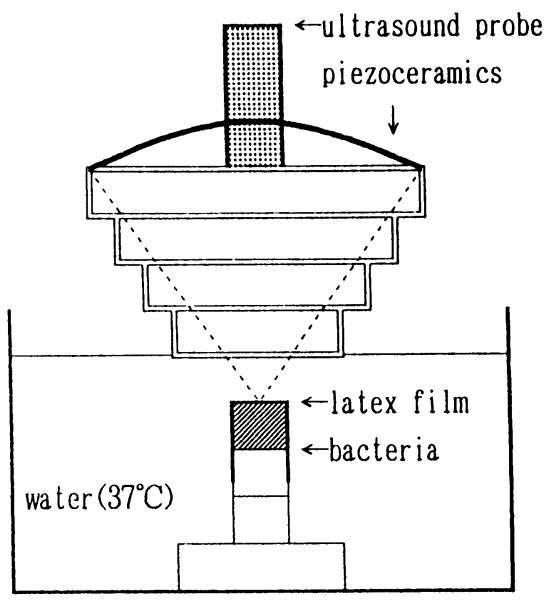

II. high pressure type

I. low pressure type

Fig. 1 Experimental setup for shock waves treatment of bacterial strains 


\section{4）生菌数の測定}

前培養菌液は衝撃波を照射した後, Vogel Bonner 緩 衝液により段階的に $10^{6}$ 倍に希釈した。ここから，100 $\mu 1$ を滅菌試験管に分注し， $45^{\circ} \mathrm{Cに}$ に保温したソフトアガーを $2 \mathrm{ml}$ 加え, よく混命した後, 予め調製しておいた栄養 寒天培地に重層した。これを $1 〜 2$ 日間, $37^{\circ} \mathrm{C} て ゙$ 培養後, 出現したコロニー数をカウントした。

\section{3. 結果および考察}

\section{1）衝撃波の变異原性}

衝撃波は一般にその強度（ピーク厈），照射回数，照 射閵隔の 3 つの要素で規定される。

そこでまずはじめに，強度を０から100MPaまで変化 させた場命の変異原性と, 試験菌の生存数を調べた。結 果をTable 1 にまとめた。

S. typhimurium TA98, TA100, TA97, TA102につい
て試験を行った結果，菌種，S9 mix の有無にかかわら ず衝撃波には変異原性は認められなかった。また, 生菌 数にも変化は認められなかった。衝撃波の強度を $100 \mathrm{MPa}$ に固定し, 照射回数を 0 から3000回まで変化さ せた場合の結果をTable 2 に示した。復帰変異コロニー 数の増加は認められなかったが, 生菌数がわずかながら 減少する傾向が認められた。衝撃波の強さを20MPaに 固定し, 照射回数を毎秒 1 回から 5 回まで増やして試験 を行った場合にも変異原性は認められなかった（Table $3)$ 。

実際の診療では60Mpa から $100 \mathrm{Mpa}$ のピーク压の衝撃 波が用いられることが多いが, 今回の結果ではこの条件 下でも衝撃波に変異原性は確認されなかった。

大島ら゙は umuテストによる試験結果から，撃波には 変異原性は認められないと述べているが, 今回の $S$. typhimurium を用いたAmesテストに扔いても変異原性

Table 1 Mutagenicity of of shock waves ( I ) (Effect of peak pressure of shock waves)

1)S. typhimurium TA98

\begin{tabular}{|c|c|c|c|c|c|c|c|c|c|}
\hline \multicolumn{2}{|c|}{ press. int. } & \multirow{2}{*}{$\frac{\text { freq. }}{[\mathrm{n}]}$} & \multicolumn{3}{|c|}{$+S 9 \operatorname{mix}$} & \multicolumn{3}{|c|}{-59 mix } & \multirow{2}{*}{$\begin{array}{c}\text { survivors } \\
{\left[\times 10^{9}\right]}\end{array}$} \\
\hline$[\mathrm{MPa}]$ & {$[\mathrm{n} / \mathrm{sec}]$} & & \multicolumn{2}{|c|}{ [rev./plate] } & (mean) & \multicolumn{2}{|c|}{ [rev./plate] } & (mean) & \\
\hline 0 & 2 & 300 & 38 & 41 & $(40)$ & 29 & 24 & (27) & 2.5 \\
\hline 20 & 2 & 300 & 25 & 35 & (30) & 45 & 38 & (42) & 2. 3 \\
\hline 40 & 2 & 300 & 33 & 44 & (39) & 35 & 24 & (30) & 2.3 \\
\hline 60 & 2 & 300 & 35 & 35 & (35) & 38 & 28 & (33) & 2. \\
\hline 80 & 2 & 300 & 28 & 33 & (31) & 38 & 29 & (34) & 2.5 \\
\hline 100 & 2 & 300 & 22 & 43 & (33) & 40 & 41 & (41) & 2.5 \\
\hline 100 & 2 & 900 & 38 & 39 & (39) & 39 & 35 & (37) & 2.6 \\
\hline \multicolumn{3}{|c|}{$\begin{array}{l}\mathrm{B}(\mathrm{a}) \mathrm{P}(5 \mu \mathrm{g} / \mathrm{plate}) \\
\mathrm{AF}-2(0.1 \mu \mathrm{g} / \mathrm{plate})\end{array}$} & 341 & 364 & (353) & $-\overline{360}$ & $-\overline{382}$ & (1) & \\
\hline
\end{tabular}

*B(a)P : bezo(a)pyrene

**AF-2 : 2-(2-furyl)-3-(5-ni tro-2-furyl)acrylamide

2)S. typhimurium TA100

\begin{tabular}{|c|c|c|c|c|c|c|c|c|c|}
\hline \multirow{2}{*}{$\frac{\text { press }}{[\mathrm{MPa}]}$} & \multirow{2}{*}{$\frac{\text { int. }}{[\mathrm{n} / \mathrm{sec}]}$} & \multirow{2}{*}{$\frac{\text { freq. }}{\text { [n] }}$} & \multicolumn{3}{|c|}{+ S9mix } & \multicolumn{3}{|c|}{$-59 \operatorname{mix}$} & \multirow{2}{*}{$\begin{array}{c}\text { survivors } \\
{\left[\times 10^{9}\right]}\end{array}$} \\
\hline & & & [rev. & [ate] & (mean) & [rev. & plate] & $\overline{(\text { mean })}$ & \\
\hline 0 & 2 & 300 & 72 & 73 & (73) & 101 & 103 & (101) & 2.6 \\
\hline 20 & 2 & 300 & 83 & 83 & (83) & 92 & 84 & ( 88$)$ & 2.6 \\
\hline 40 & 2 & 300 & 73 & 71 & (72) & 91 & 106 & ( 99$)$ & 2. \\
\hline 60 & 2 & 300 & 84 & 86 & (85) & 80 & 118 & ( 99 ) & 2. \\
\hline 80 & 2 & 300 & 73 & 92 & (83) & 96 & 83 & ( 90$)$ & 2. 3 \\
\hline 100 & 2 & 300 & 75 & 86 & (81) & 93 & 95 & (94) & \\
\hline 100 & 2 & 900 & 94 & 75 & (85) & 80 & 65 & ( 73) & 2.3 \\
\hline \multicolumn{3}{|c|}{$\begin{array}{l}\mathrm{B}(\mathrm{a}) \mathrm{P}(5 \mu \mathrm{g} / \text { plate }) \\
\mathrm{AF}-2(0 / \text { olate })\end{array}$} & 523 & 491 & (507) & $-\overline{-}$ & $\overline{344}$ & & \\
\hline
\end{tabular}

*B(a)P $\vdots$ bezo(a)pyrene

**AF-2 : 2-(2-furyl)-3-(5-nitro-2-furyl)acrylamide 


\begin{tabular}{|c|c|c|c|c|c|c|c|c|c|}
\hline \multirow{2}{*}{\multicolumn{2}{|c|}{$\frac{\text { press. int. }}{[\mathrm{MPa}][\mathrm{n} / \mathrm{sec}]}$}} & \multirow{2}{*}{$\frac{\text { freq. }}{[\mathrm{n}]}$} & \multicolumn{3}{|c|}{$+59 \operatorname{mix}$} & \multicolumn{3}{|c|}{-S9mix } & \multirow{2}{*}{$\begin{array}{l}\text { survivors } \\
{\left[\times 10^{9}\right]}\end{array}$} \\
\hline & & & \multicolumn{2}{|c|}{ [rev./plate] } & $\overline{(m e a n)}$ & \multicolumn{2}{|c|}{ [rev./plate] } & \multirow{2}{*}{$\frac{(\text { mean })}{(195)}$} & \\
\hline 0 & 2 & 300 & 215 & 226 & (221) & 199 & 191 & & 26 \\
\hline 20 & 2 & 300 & 247 & 209 & (228) & 185 & 180 & (183) & 25 \\
\hline 40 & 2 & 300 & 237 & 240 & (239) & 196 & 180 & (188) & 2.5 \\
\hline 60 & 2 & 300 & 239 & 251 & (245) & 195 & 179 & (187) & 2.5 \\
\hline 80 & 2 & 300 & 240 & 290 & (265) & 221 & 213 & (217) & 3. 1 \\
\hline 100 & 2 & 300 & 226 & 237 & (232) & 180 & 209 & (195) & 3.0 \\
\hline 100 & 2 & 900 & 244 & 214 & (229) & 178 & 195 & (187) & 2.7 \\
\hline \multicolumn{3}{|c|}{$\begin{array}{l}\text { 2-AA (1 } \mu \mathrm{g} / \text { plate }) \\
\text { ICR191(0.05 } \mu \mathrm{g} / \text { plate })\end{array}$} & 1092 & 1172 & (1132) & 808 & $\frac{-}{812}$ & (810) & \\
\hline
\end{tabular}

*2-AA : 2-amino-anthracene

4)S. typhimurium TA102

\begin{tabular}{|c|c|c|c|c|c|c|c|c|c|}
\hline \multirow{2}{*}{\multicolumn{2}{|c|}{$\frac{\text { press. int. }}{[\mathrm{MPa}][\mathrm{n} / \mathrm{sec}]}$}} & \multirow{2}{*}{$\frac{\text { freq. }}{[\mathrm{n}]}$} & \multicolumn{3}{|c|}{$+59 \operatorname{mix}$} & \multicolumn{3}{|c|}{$-S 9 \operatorname{mix}$} & \multirow{2}{*}{$\begin{array}{l}\text { survivors } \\
{\left[\times 10^{9}\right]}\end{array}$} \\
\hline & & & \multicolumn{2}{|c|}{ [rev./plate] } & (mean) & \multicolumn{2}{|c|}{ [rev./plate] } & (mean) & \\
\hline 0 & 2 & 300 & 214 & 177 & (196) & 187 & 242 & (215) & 2.5 \\
\hline 20 & 2 & 300 & 250 & 248 & (249) & 241 & 225 & (233) & 2.7 \\
\hline 40 & 2 & 300 & 275 & 251 & (263) & 255 & 186 & (221) & 2. 6 \\
\hline 60 & 2 & 300 & 277 & 270 & (274) & 271 & 260 & (266) & 2.8 \\
\hline 80 & 2 & 300 & 292 & 255 & (274) & 271 & 271 & (271) & 2.8 \\
\hline 100 & 2 & 300 & 275 & 285 & (280) & 271 & 273 & (272) & 2.4 \\
\hline 100 & 2 & 900 & 264 & 308 & (286) & 295 & 275 & (285) & 2.5 \\
\hline \multirow{2}{*}{\multicolumn{3}{|c|}{$\begin{array}{l}2-\mathrm{AA}(1 \mu \mathrm{g} / \mathrm{plate}) \\
\operatorname{MC}(0.005 \mu \mathrm{g} / \text { plate })\end{array}$}} & 665 & 606 & (636) & - & - & & \\
\hline & & & & & & 380 & 330 & (355) & \\
\hline
\end{tabular}

は認められなかった。

\section{2）変異原物質に対する重波の影整}

衝撃波を照射した菌としない菌について変異原物質に 対する応答を比較した。試験菌としてTA98を用い, 13 時間前培養した菌液に，10〜20 MPaの衝撃波を毎秒 1 回の間隔で, 300 回照射したものを用いた。結果を Table 4 に示した。B(a)P, AF-2について検討を行った が, 衝撃波を照射した菌としない菌とで有意の差は認め られなかった。

次に, 試験菌と変異原物質の混合溶液に対する衝撃波 照射の影響について検討を行った。試験菌はS. typhimurium TA98, TA100, TA97, TA102の 4 種とし, そ れぞれ13時間前培養したものを用いた。また，変異原物 質としてシスプラチンを，衝撃波の照射はピーク圧 $100 \mathrm{MPa}$, 照射間隔は毎秒 2 回, 照射回数は 1000 回とした。
シスプラチンは抗腫瘍性を有する白金化合物で膀胱癌, 腎孟・尿管腫瘍，胃癌などに広く用いられているが，S． typhimurium TA98, TA100に変異原性を有することが知 られている。結果をTable 5 にまとめた。

いずれの菌についても, 衝撃波を照射した場合は，し ない場合に比べ，シスプラチンの变異原性，細胞毒性が 共にやや増強される傾向が認められた。

廣田ら ${ }^{5,6)}$ は磁場の遺伝子への影響について Ames テ ストや小核試験により検討を行い，磁場そのものには変 異原性は認められないものの, 種々の化学変異原に対し 活性修飾作用（増強作用，抑制作用）を有することを示 している。

このような物理作用による变異原活性修飾の作用機構 については必ずしも明らかではないが，化学物質の生物 活性の発現に物理作用が影響しているという点で大変に 興味深い。 
Table 2 Mutagenicity of of shock waves ( II ) (Effect of frequency of shock wave shots)

1)S. typhimurium TA98

\begin{tabular}{|c|c|c|c|c|c|c|c|c|c|}
\hline \multirow{2}{*}{\multicolumn{2}{|c|}{$\frac{\text { press. int. }}{[\mathrm{MPa}][\mathrm{n} / \mathrm{sec}}$}} & \multirow{2}{*}{$\frac{\text { freq. }}{[\mathrm{n}]}$} & \multicolumn{3}{|c|}{$+\$ 9 \operatorname{mix}$} & \multicolumn{3}{|c|}{$-S 9 \operatorname{mix}$} & \multirow{2}{*}{$\begin{array}{c}\text { survivors } \\
{\left[\times 10^{9}\right]}\end{array}$} \\
\hline & & & [rev.] & late] & $($ mean) & [rev. & late] & (mean) & \\
\hline 100 & 2 & 0 & 40 & 59 & (50) & 35 & 47 & (41) & 2. 1 \\
\hline 100 & 2 & 1000 & 72 & 71 & (72) & 57 & 44 & (51) & 2.0 \\
\hline 100 & 2 & 3000 & 80 & 85 & (83) & 43 & 61 & (52) & 1.8 \\
\hline \multicolumn{3}{|c|}{$\mathrm{B}(\mathrm{a}) \mathrm{P}(5 \mu \mathrm{g} / \mathrm{plate})$} & 447 & \multirow{2}{*}{\multicolumn{2}{|c|}{$447(447)$}} & - & - & \multirow[b]{2}{*}{ (382) } & \\
\hline$A F-2$ & $(0.1 \mu \mathrm{g}$ & /plate) & 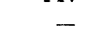 & & & 388 & 376 & & \\
\hline
\end{tabular}

* B(a)P : bezo (a)pyrene

** AF-2 :2-(2-furyl)-3-(5-nitro-2-furyl)acry lamide

2)S. typhimuriun TA100

\begin{tabular}{|c|c|c|c|c|c|c|c|c|c|}
\hline \multirow{2}{*}{\multicolumn{2}{|c|}{$\frac{\text { press. int. }}{[\mathrm{MPa}][\mathrm{n} / \mathrm{sec}]}$}} & \multirow{2}{*}{$\frac{\text { freq. }}{[\mathrm{n}]}$} & \multicolumn{3}{|c|}{$+S 9 \operatorname{mix}$} & \multicolumn{3}{|c|}{$-S 9 \operatorname{mix}$} & \multirow{2}{*}{$\begin{array}{c}\text { survivors } \\
{\left[\times 10^{9}\right]}\end{array}$} \\
\hline & & & [rev. / & late] & (mean) & [rev. & olate] & (mean) & \\
\hline 100 & 2 & 0 & 87 & 106 & ( 97) & 119 & 117 & (118) & 2. 6 \\
\hline 100 & 2 & 1000 & 111 & 123 & (117) & 134 & 120 & (127) & 2.4 \\
\hline 100 & 2 & 3000 & 93 & 83 & ( 88$)$ & 123 & 107 & (115) & 1.7 \\
\hline \multicolumn{3}{|c|}{$\begin{array}{l}\mathrm{B}(\mathrm{a}) \mathrm{P}(5 \mu \mathrm{g} / \text { plate }) \\
\mathrm{AF}-2(0 \mathrm{l} \mu \mathrm{g} / \text { plate })\end{array}$} & 611 & \multicolumn{2}{|c|}{$646(629)$} & - & - & (345) & \\
\hline
\end{tabular}

* B(a)P : bezo(a)pyrene

** AF-2 :2-(2-furyl)-3-(5-nitro-2-furyl)acrylamide

3)S. typhimurium TA97

\begin{tabular}{|c|c|c|c|c|c|c|c|c|c|}
\hline \multicolumn{2}{|c|}{ press. int. } & \multirow{2}{*}{ freq. } & \multicolumn{3}{|c|}{ +SOmix } & \multicolumn{3}{|c|}{-S9mix } & \multirow{2}{*}{$\begin{array}{c}\text { survivors } \\
{\left[\times 10^{9}\right]}\end{array}$} \\
\hline$[\mathrm{MPa}]$ & {$[\mathrm{n} / \mathrm{sec}]$} & & \multicolumn{2}{|c|}{ [rev./plate] } & (mean) & \multicolumn{2}{|c|}{ [rev./plate] } & \multirow{2}{*}{$\frac{(\text { mean })}{(232)}$} & \\
\hline 100 & 2 & 0 & 268 & 275 & (272) & 222 & 241 & & 2. 3 \\
\hline 100 & 2 & 1000 & 299 & 274 & (287) & 259 & 259 & (259) & 2.1 \\
\hline 100 & 2 & 3000 & 274 & 297 & (286) & 237 & 252 & (245) & 1.1 \\
\hline \multirow{2}{*}{\multicolumn{3}{|c|}{$\begin{array}{l}\text { 2-AA (1 } \mu \mathrm{g} / \mathrm{plate}) \\
\text { ICR191 }(0.05 \mu \mathrm{g} / \mathrm{plate})\end{array}$}} & 973 & 936 & (955) & - & - & & \\
\hline & & & - & - & & 773 & 625 & 699） & \\
\hline
\end{tabular}

*2-AA : 2-amino-anthracene

4)S. typhimurium TA102

\begin{tabular}{|c|c|c|c|c|c|c|c|c|c|}
\hline \multirow{2}{*}{\multicolumn{2}{|c|}{ press. int. }} & \multirow{2}{*}{$\frac{\text { freq. }}{[\mathrm{n}]}$} & \multicolumn{3}{|c|}{+ S9mix } & \multicolumn{3}{|c|}{$-S 9$ mix } & \multirow{2}{*}{$\begin{array}{c}\text { survivors } \\
{\left[\times 10^{9}\right]}\end{array}$} \\
\hline & {$[\mathrm{n} / \mathrm{sec}]$} & & \multicolumn{2}{|c|}{ [rev./plate] } & $($ mean) & \multicolumn{2}{|c|}{ [rev./plate] } & (mean) & \\
\hline 100 & 2 & 0 & 341 & 391 & (366) & 185 & 147 & (166) & 2.8 \\
\hline 100 & 2 & 1000 & 345 & 353 & (249) & 226 & 210 & (218) & 2.2 \\
\hline 100 & 2 & 3000 & 355 & 315 & (335) & 242 & 246 & （244） & 2.1 \\
\hline \multirow{2}{*}{\multicolumn{3}{|c|}{$\begin{array}{l}2 \text { AA (1 } 1 \mu \mathrm{g} / \text { plate }) \\
\operatorname{MC}(0.005 \mu \mathrm{g} / \text { plate })\end{array}$}} & 502 & 551 & (527) & - & - & & \\
\hline & & & - & & & 293 & 297 & （295） & \\
\hline
\end{tabular}

* 2-AA : 2-amino-anthracene

** MC : Mitomycin C 
Table 3 Mutagenicity of of shock waves (III) (Effect of intervals of shock wave shots)

1) S. typhimaurium TA98

\begin{tabular}{|c|c|c|c|c|c|c|c|c|}
\hline \multirow{2}{*}{\multicolumn{3}{|c|}{$\begin{array}{ccc}\text { press. int. } & \text { freq. } \\
{[\mathrm{MPa}]} & {[\mathrm{n} / \mathrm{sec}]} & {[\mathrm{n}]}\end{array}$}} & \multicolumn{3}{|c|}{$+\operatorname{simix}$} & \multicolumn{3}{|c|}{-S9mix } \\
\hline & & & [rev. & late] & (mean) & [rev. & late] & (mean) \\
\hline - & - & 0 & 41 & 33 & (37) & 35 & 23 & （29） \\
\hline 20 & 1 & 45 & 34 & 41 & (33) & 24 & 20 & （22） \\
\hline 20 & 1 & 150 & 42 & 50 & (46) & 27 & 28 & (28) \\
\hline 20 & 1 & 300 & 37 & 42 & (40) & 29 & 36 & (33) \\
\hline 20 & 5 & 300 & 56 & 38 & (47) & 31 & 22 & (27) \\
\hline 20 & 5 & 1000 & 49 & 45 & (47) & 28 & 25 & （27） \\
\hline 20 & 5 & 3000 & 52 & 39 & (46) & 29 & 20 & （25） \\
\hline
\end{tabular}

2) S. typhimurium TA100

\begin{tabular}{|c|c|c|c|c|c|c|c|c|}
\hline \multirow{2}{*}{\multicolumn{3}{|c|}{$\begin{array}{ccc}\text { press. } & \text { int. } & \text { freq. } \\
{[\mathrm{MPa}]} & {[\mathrm{n} / \mathrm{sec}]} & {[\mathrm{n}]}\end{array}$}} & \multicolumn{3}{|c|}{ +S9mix } & \multicolumn{3}{|c|}{-S9mix } \\
\hline & & & [rev. & late & (mean) & [rev. & plate] & (mean) \\
\hline $\begin{array}{ll}- & \text { r }\end{array}$ & - & 0 & 72 & 102 & （87） & 86 & 94 & (90) \\
\hline 20 & 1 & 45 & 72 & 81 & (77) & 77 & 88 & (83) \\
\hline 20 & 1 & 3000 & 96 & 89 & (93) & 79 & 85 & (82) \\
\hline 20 & 1 & 300 & 74 & 75 & (75) & 88 & 100 & (96) \\
\hline
\end{tabular}

Table 4 Mutagenic responses of shock wave treated thester strains

1) S. typhimurium $\mathrm{TA98},+\mathrm{S} 9 \mathrm{mix}$

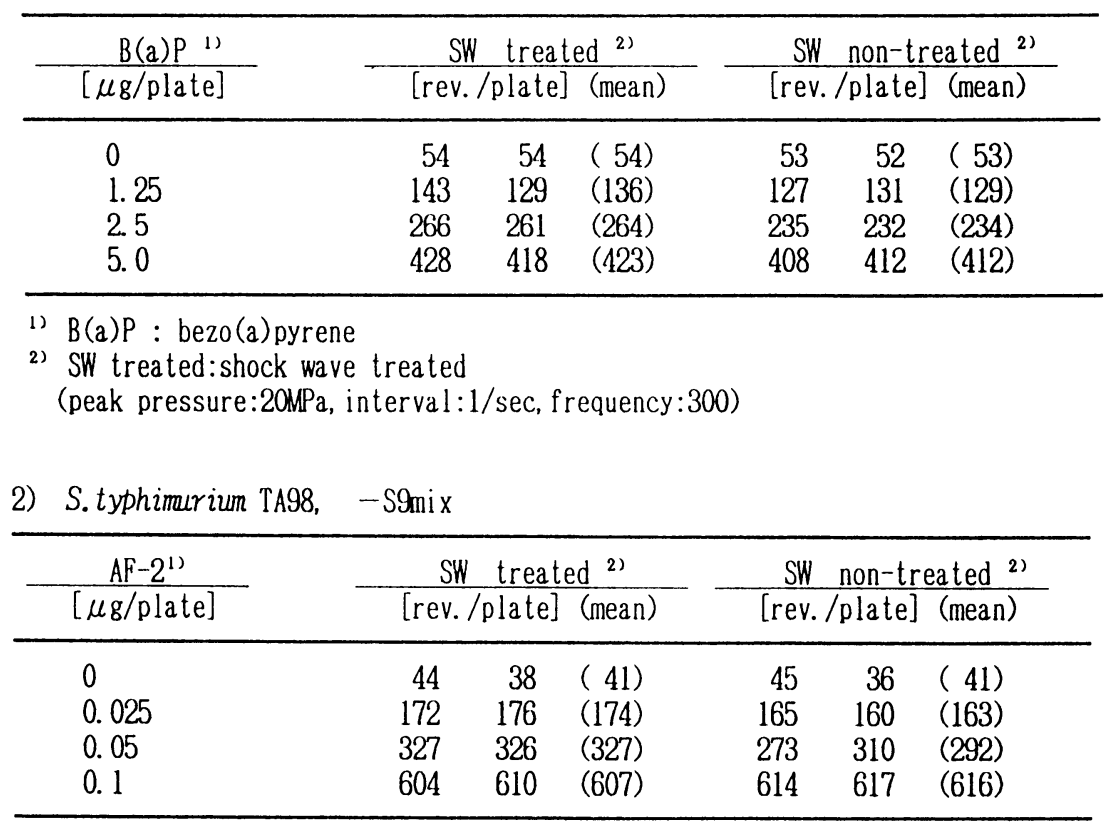

1) AF-2:2-(2-furyl)-3-(5-nitro-2-furyl)acrylamide

2) $\mathrm{SW}$ treated:shock wave treated

(peak pressure:20MPa, interval:1/sec, frequency:300) 
Table 5 Mutagenic effects of shock waves of the mixture of CDDP and tester strains

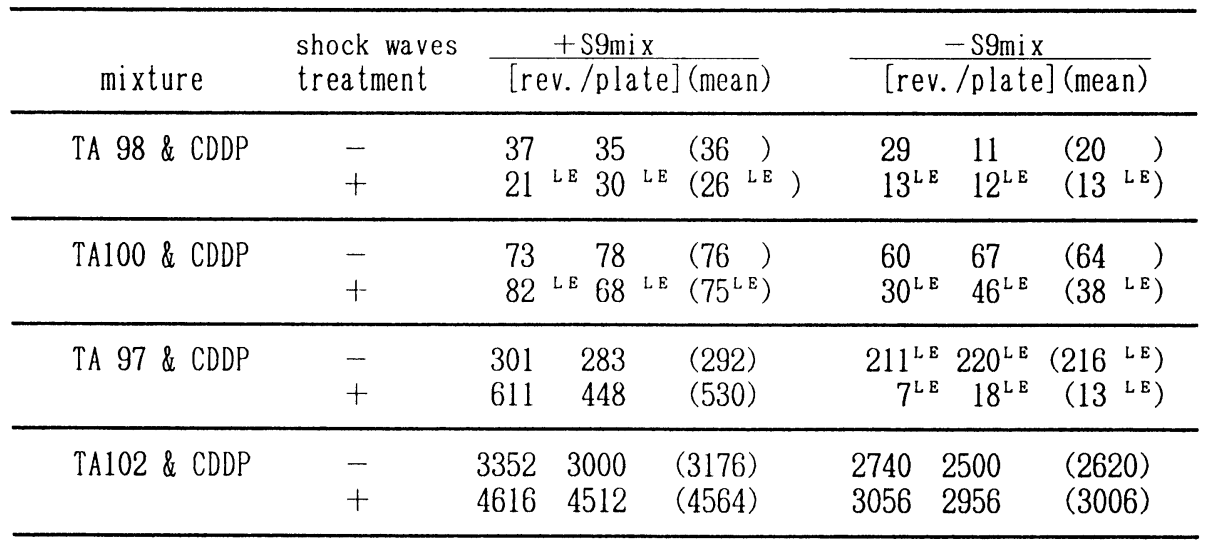

* 3ml of CDDP (cis-diamine dichloroplatinum) solution $(50 \mu \mathrm{g} / \mathrm{ml})$ was mixed to bacterial solution $(3 \mathrm{ml})$.

$200 \mu 1$ of this mixture was used for mutation test.

Final dose of CDDP is $5 \mu \mathrm{g} / \mathrm{plate}$.

* SW: shock wave

(peak pressure:100MPa, interval:2/sec, frequency:1000)

*** LE: lethal effect

\section{4.おわりに}

超音波などの物理作用の変異原性については，最近い くつかの報告がなさ机ている。

Libeskind ら ${ }^{7.8 .9)}$ は診断用超音波について, ヒトリン 八゚球を用いた姉妹染色分体交換（SEC）により，変異原 性が認められたと報告している。しかし，超音波に変異 原性が認められたとする報告は少なく ${ }^{10.11}$, Morris $ら^{10)}$ やWegner $ら^{11.12)}$ を始め, 大半の報告ではSECで 変異原性は認められていない。さらに, Wegner $ら^{12,13)}$ はAmesテストにより変異原性を調へ，変異原性は認め られないと述べている。

本研究では衝撃波の変異原性, 変異原性修飾作用につ いてAmesテストを用い検討した。その結果, 衝撃波の ピーク圧, 照射回数, 照射間隔のいずれを変化させた場 合にも変異原性は認められなかった。また，変異原物質 (CDDP) と試験菌との混合液に衝撃波を照射した場合 には, CDDPの変異原性, 細胞毒性共にやや増強される ことがわかった。

庵谷ら ${ }^{1}$ は，犬を用いた実駼結果から，衝撃波照射に よって腎組織に障害の生じる可能性のあることを指摘し ている。微生物と動物では細胞の膜組織が音響学的に大 きく異なることから，今後は動物細胞を用い同様の試験 を行っていく必要があると考えられる。

\section{要 約}

体外衝撃波療法は水中衝撃波の照射により腎結石や膀 胱結石を破砕する治療手段である。しかし，その遺伝的 影響に関しては必ずしも明らかではない。本研究では エームズテストを用いて衝撃波の変異原性について検討 を行った。試験菌（TA98，TA100，TA97，TA102）お よび試験菌と変異原の混合液を衝撃波発生装置の焦点領 域にセットし衝撃波を照射した。衝撃波の最高圧力を0 から100MPa まで変化させたが, 菌種, S9mixの有無に 係わらず衝撃波には変異原性は認められなかった。試験 菌とシスプラチン（CDDP）の混合液に衝撃波を照射し た場合には，CDDPの変異原性や細胞毒性が増強された。 このことから, 衝撃波は化学物質の遺伝毒性を増強する 可能性のあることが示唆された。

\section{文 献}

1) Ioritani, N. and Kuwahara, M.: Renal tissue damage induced by focused shock waves. AIP Conf.Proc., 208-Current Topics in Shock Wares, Am. Inst. Physics. 831-836 (1989)

2) 大島敏久, 田中悟広, 手島光间: 微生物細胞拉よび

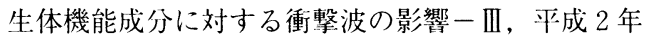
度衝撃波シンポジウム講演論文集，71-72p（1990）

3）大島敏久, 田中悟広, 西谷泰子, 手島光司: 微生物 
細胞および生体機能成分に対する衝撃波の影響一 IV 評価法の検討, 平成 3 年度衝撃波シンポジウム 講演論文集, 315-316p (1992)

4) Ames, B.N., McCann, J. and Yamazaki, E.: Method for detecting carcinogens and mutagens with the Salmonella / mammalian-microsome mutagenicity test. Mutation Res., 31, 347-364 (1975)

5）廣田秀美，鈴木勇司，清水英祐，磁場の変異原性に 与之る影響, 第16回日本環境变異原学会講演要旨集, 113p（1987）

6）清水英祐，檜山雅子, 鈴木勇司，林 和夫：磁場の 变異原性に与える影響（第 2 報）。第17回日本環境 变異原学会講演要旨集, 68p (1988)

7) Liebeskind, D.: Sister chromatid exchanges in human lymphocytes after exposure to diagnostic ultrasound. Science, 205, 1273-1275 (1979)

8) Barnett, S. and Kossoff, G.: Temporal peak intensity as a crinical parameter in ultrasound dosimetry. $J$. Ultrasound Med., 3. 385-389 (1984)

9) Haupt. M.: Ultrasonic induction of sister chromatid exchanges in human lymphocytes. Hum. Gent., 59,
221-226 (1981)

10) Morris, S., Palmer, C., Fry, F. and Johnson: Effect of ultrasound on human lymphocytes. Sister chromatid exchange analysis. Ultrasound Med. Biol., 4, 253-258 (1978)

11) Wegner, R.D. and Meyenburg, M.: The effects of diagnostic ultrasonography on the frequencies of sister chromatid exchanges in chinese hamster cells and human lymphocytes. Ultrasound Med., 1, 355-358 (1982)

12) Wegner, R.D. and Lang, R.: Absence of mutagenic effect of diagnostic ultrasound in the Salmonella muatagenicity test (Ames test). IEEE Transactionon on ultrasonics, ferroelectrics, and frequency control, UFFC 33(2), 171 (1986)

13) Meyenberg, M., Lang, R., Saling, E., and Wegner, R.D.: Has pulse-doppler ultrasound mutagenic effects? Application of the Ames mutagenicity assay to test pulse-doppler equipment. Echocardiography, $A$ Jml. of CV Ultrasound \& Allied Tech. 7(5), 1-4 (1990) 